\title{
Isolation, Identification and Antibiosis Efficacy of Marine Thermophilic Actinomycetes
}

\author{
Sahar Yassin Ibrahim ${ }^{\#}$ \\ Botany Department, Faculty of Women for Arts, Science and Education, Ain Shams \\ University, Cairo, Egypt.
}

\begin{abstract}
7 HIS WORK is aimed to assess the antibiosis efficacy of marine thermophilic actinomycetes isolated from raw marine habitat and identify the most antibiosis effective isolate. Variable thermophilic actinomycete strains were isolated from 14 marine sediment samples at Burj Al Arab, El-Agamy salinases and Cairo-Alex route Alexandria, Egypt. The isolated strains were purified and screened for their antibiosis activities against various targets of human pathogenic bacteria and fungi. Actinomycete isolate, characterized by highest broad-spectrum antagonism, was selected and identified based on morphological, cultural, physiological and biochemical characteristics. Total cell hydrolysate analysis, Genomic DNA extraction and 16S rRNA sequencing were also characterized. Among the purified 135 marine thermophilic actinomycete isolates, twenty strains showed detectable antagonistic activities against test pathogens. Based on identification collected data, it was suggested that the most potent undertreat isolate is belonging to actinomycete genus Saccharomonospora. Molecular studies revealed that it was highly related to Saccharomonospora viridis (100\%). As a result, it was designated as Saccharomonospora viridis AHK190.
\end{abstract}

Keywords: Actinomycetes, Antibiosis, Identification, Marine, Thermophilic.

\section{Introduction}

Natural products have been the major source of numerous therapeutic agents producing more than a half of the drugs in use today in many therapeutic categories. Discovering new natural therapeutic agents is driven by the need to combat the increase in the incidence of infection due to antibiotic resistant pathogens coupled with the search for antitumor and antiviral compounds (Eccleston et al., 2008). In spite of the heavily studied concerning pharmaceutically relevant microorganisms, actinomycetes continue to prove themselves as reliable sources of novel bioactive compounds; they remain one of major sources of novel therapeutically relevant natural products (Messaoudi et al., 2015; Trabelsi et al., 2016 and Ganesan et al., 2017). The taxonomic and ecological positions of antibiotic producing actinomycetes are well recognized for their metabolic flexibility, commonly accompanied by the production of primary and secondary metabolites of economic significance (Sharma et al., 2014). However, screening for novel actinomycetes constitutes an essential component in natural product-based drug discovery. On the other hand, the increasing number of novel metabolites from marine microorganisms shows that marine habitats are a promising source of biotechnological commercially significant products (Blunt et al., 2007). Marine microorganisms> diversity have been studied and biotechnologically exploited throughout the world; they continue to provide pharmacologically important secondary metabolites which are unique and novel chemical compounds (Trabelsi et al., 2016). Much interest on the screening of marine and aquatic microorganisms is focused on screening of sediment derived microorganisms and also on those that of highly specific symbiotic associations with marine plants and animals (Eccleston et al., 2008). They produce different types of antibiotics, because the marine environmental conditions differ greatly from terrestrial conditions (Kokare et al., 2004). Marine actinomycetes have been traditionally a rich source for biologically active metabolites and also constitute an important and potential source of novel bioactive compounds; new actinomycetes with biopharmaceutical potential have been increasingly isolated from

\footnotetext{
"Corresponding author: Sahar Yassin Ibrahim Lecturer of Microbiology Botany Department Faculty of Women for Arts, Science and Education Ain Shams University, Cairo, Egypt. Address: Asmaa Fahmy Street - Heliopolis - Cairo - Egypt.

Tel: $+20-100-6556388$

E-mail: sahar_moussa@women.asu.edu.eg

DOI :10.21608/ejm.2017.2021.1034

C2017 National Information and Documentation Center (NIDOC)
} 
marine habitats (Valli, et al., 2012; Sengupta et al. 2015 and Subramanian et al., 2017). The majority of these compounds demonstrate one or more bioactivities many of them developed into drugs for treatment of wide range of diseases in human, veterinary and agriculture sectors (Battershill et al., 2005 and Kafilzadeh \& Dehdari, 2015). It is now accepted that actinomycetes can be indigenous to the marine environment and that this environment is likely to yield many unusual actinomycetes potential of producing novel antibiotics and other compounds. Most description of actinomycete species was, at first, based on their morphological features alone; although considerable progress has been made in recent years in the taxonomy of actinomycetes. Recent actinomycetes identification parameters involved cell wall chemotype, cell sugar detection, physiological and molecular studies. Traditional and recent descriptions of actinomycetes taxonomy were collected in Bergey's Manual of Systematic Bacteriology (Whitman et al., 2012).

As a result of references' survey, thermophilic marine actinomycetes were not so lucky so far to be investigated; so present study was designed to isolate and purify various thermophilic strains of actinomycetes isolated from marine environments in Egypt; assess their antibiosis efficiency against different Gram+ve and Gram-ve bacterial and fungal test human pathogens; select and identify the most significant broad-spectrum antagonistic isolate.

\section{Materials and Methods}

Samples collection

Water and soil sediment samples were collected from three salinases, Burj Al-Arab, ElAgamy and Alex-Egypt rout (Alexandria-Egypt). Sediments were collected at 5-15 cm depth.

\section{Preparation of sediment samples}

Sediment samples were treated as soon as possible after collection using: 1- Heat shock method (Gontang et al., 2007), it was used as an enrichment selective method for isolation of actinomycetes; it was proceeded as follow: 1.0 $\mathrm{g}$ of wet sediment was added to $4 \mathrm{ml}$ of sterile sea water, heated for $6 \mathrm{~min}$ at $55^{\circ} \mathrm{C}$, vigorously shaken then diluted $(1: 4 \mathrm{v} / \mathrm{v})$ in sterile sea water. 2- Calcium carbonate treatment (El-Nakeeb \& Lechevalier, 1962), air dried sediment samples $(1.0 \mathrm{~g})$ were mixed in a mortar with $1.0 \mathrm{~g}$ of calcium carbonate. Each $\mathrm{CaCO}_{3}$ sediment mixture was incubated for 5 days at $55^{\circ} \mathrm{C}$.

\section{Isolation and purification of actinomycetes}

Different cultural media were used for actinomycetes isolation and purification with some modifications. Starch nitrate agar medium (SNA) (diffco); Starch casein agar medium (SCA) (diffco) (Reddy et al., 2011), Jensen agar medium. All media were prepared using artificial sea water instead of distilled water. Artificial sea water is composed of $\mathrm{NaCl}: 24 \mathrm{~g}, \mathrm{MgSO}_{4} .7 \mathrm{H}_{2} \mathrm{O}: 7 \mathrm{~g}$, $\mathrm{MgCl}_{2} \cdot 6 \mathrm{H}_{2} \mathrm{O}: 5.3 \mathrm{~g}, \mathrm{KCl}: 0.7 \mathrm{~g}, \mathrm{CaCl}_{2}: 0.1 \mathrm{~g}$ and $1.0 \mathrm{~L}$ distilled water. Each of isolation media was supplemented with yeast extract $(2.0 \mathrm{~g} / \mathrm{L})$, rifampin (5.0 mg/L) (Pisano et al., 1989) and nystatin $(50 \mathrm{mg} / \mathrm{L})$. Culture media were also provided with four $\mathrm{NaCl}$ concentrations: 2.4, 5.0, 7.0, and $9.0(\mathrm{~g} / 100 \mathrm{ml})$ performing four sets for each medium. Sterilized Petri dishes, in triplicates, containing media were inoculated and incubated at $55^{\circ} \mathrm{C}$ for one week. One $\mathrm{ml}$ of water sample and $1.0 \mathrm{ml}$ of previously prepared wet sediment solution was used for inoculation proceeding pour plate method; while inoculums of aliquot amounts of each air dried $\mathrm{CaCO}_{3}$ supplemented sediment samples were homogenously scattered using sterile spatula on the surface of Petri dish solidified media. After incubation, formed actinomycete colonies were counted (CFU/g) and purified by streak manner and sub-cultured on SCA. Standard Deviation (SD) of actinomycetes average count was calculated for each sediment sample on SNA; SD was assessed following Standard Deviation Calculator (2008-2017).

\section{Test microorganisms}

Antibacterial assay was tested against IStaphylococcus aureus (NCTC 10788/ATCC 6538), Escherichia coli (NCTC 10418/ATCC 10536), Bacillus cereus (NCTC 7464/ATCC 10876), Pseudomonas aeruginosa (NCTC 10662 /ATCC 25668), and Bacillus subtlis. While, test fungal strains were Aspergillus niger, Aspergillus flavus, Fusarium spp., Trichoderma spp. and Penicillium spp. Bacterial strains were collected from the American Type Culture Collection (ATCC). Pseudomonas aeruginosa and Bacillus subtlis were obtained from Microbiology Research Lab, Botany Department; Faculty of Women for Arts, Science and Education; Ain Shams University. Fungal strains were provided by Faculty of Agriculture; Ain Shams University; Cairo; Egypt.

Antibiosis screening assay

Antibiosis activities of all purified actinomycete isolates were surveyed through agar 
well diffusion method and expressed in terms of inhibition zones diameters (mm) (Ibrahim and Abd El-Salam, 2016). Broth (agar-free) formula of the isolation media together with $\mathrm{NaCl}$, nutrient agar (NA) (diffco) and Sabaroud's agar (diffco) (SA) were utilized. A $50 \mathrm{ml}$ broth of isolate culture was inoculated with a heavy loopful of $24 \mathrm{~h}$ age isolate culture grown at $55^{\circ} \mathrm{C}$ and incubated on a rotary shaker $(200 \mathrm{rpm})$ at $55^{\circ} \mathrm{C}$ for 3 days; $0.5 \mathrm{ml}$ of isolate culture filtrate was transferred into a well of $1.0 \mathrm{~cm}$ diameter in a $25 \mathrm{ml}$ solidified NA seeded with bacteria, and SA with fungi. Treatment was repeated three times and SD values were evaluated. Test inocula of bacteria and fungi were adjusted at 0.1 concentrations at optical densities, $620 \mathrm{~nm}$ and $530 \mathrm{~nm}$, respectively. Both NA and SA were seeded with $0.2 \mathrm{ml}$ bacterial and $0.5 \mathrm{ml}$ fungal inocula $/ 100 \mathrm{ml}$ medium. Positive controls were prepared using $0.5 \mathrm{ml}$ of each of chloramphenicol $(100 \mathrm{mg} / \mathrm{ml})$ as antibacterial and nystatin $(50 \mathrm{mg} / \mathrm{ml})$ as antifungal instead of isolate filtrate; and $0.5 \mathrm{ml}$ of sterile saline solution $(0.85 \% \mathrm{NaCl})$ for negative control. All plates were kept in the refrigerator for $2-4 \mathrm{~h}$ then incubated under conditions depended on the seeded test organism nature (at $37^{\circ} \mathrm{C}$ for $24 \mathrm{~h}$. for bacteria and $2-4$ days at $28^{\circ} \mathrm{C}$ for fungi); formed inhibition zones were then investigated. The actinomycete isolate that recorded the largest inhibition zone diameters against all or almost all of the test targets was selected as the most potent isolate and identified.

\section{Actinomycete identification}

The most potent effective isolate was identified to the genus and species levels based on International Streptomyces Project (ISP) media (Shirling \& Gottlieb, 1966) and according to Bergy' manual of systematic bacteriology (Whitman et al., 2012). Cultural, morphological, physiological, biochemical and molecular parameters in addition to chemotaxonomic analysis were characterized.

Distilled water was substituted by artificial sea water in all of the identification media.

\section{Cultural characteristics}

Cultural characterization involved visual examination of mature colony appearance and pigmentation on ISP media (diffco). Yeast malt extract agar (ISP2), oatmeal agar (ISP3), inorganic salts-starch agar (ISP4) and glycerol asparagine agar (ISP5). Colour of sporulating aerial surface, substrate mycelium as viewed from the reverse side and diffusible soluble pigments other than melanin was determined. Colour determination of mature cultures was assessed (white, gray, red, green, blue, and violet); when aerial mass colour fell between two colours series, both colours were recorded.Universal colour language and dictionary of names was consulted (Kenneth, 1976).

\section{Morphological characteristics}

Morphological characterization was also followed on ISP media, at $55^{\circ} \mathrm{C}$ for three days. Study was based on observed microscopic structure using cover slip culture technique (Williams \& Cross, 1971). Spore surface and morphology of spore bearing hyphae with the entire spore chain were characterized as described in Bergy's manual (Whitman et al., 2012). Morphological observations were conducted using transmission and scanning electron microscopy which was taken in The National Research Center, Giza; Egypt.

\section{Chemotaxonomic analysis}

Total cell hydrolysate of the under-test isolate cells was proceeded (Ibrahim, 2002). The isolate was grown in tryptone yeast broth medium ISP1 at $55^{\circ} \mathrm{C}$ for three days then cells were collected by filtration, washed with water and ethyl alcohol and air dried at room temperature. Isomers of diaminopimelic acid and whole cell sugars detection in whole cell hydrolysate were examined and evaluated by thin-layer chromatography (Staneck \& Roberts, 1974).

\section{Physiological and biochemical characteristics}

A variety of physiological and biochemical parameters were investigated according to Whitman et al. (2012); utilization of carbon sources examined on C-free basal medium plus trace salts solution (ISP 9) (Pridham \&Gottlieb, 1948); casein hydrolysis (Gordon \& Smith, 1954); gelatin liquefaction; starch hydrolysis (Gordon \& Smith, 1956); $\mathrm{H}_{2} \mathrm{~S}$ production; cellulose degradation (Demain \& Davies, 1999); urease test; tyrosine decomposition; production of melanoid pigments on tyrosine agar (ISP1), peptone yeast- iron agar (ISP6) and tryptone yeast extracts broth (ISP7) media (Shirling \& Gottlieb, 1966); nitrate reductase test (Gordon \& Smith, 1956); indole production, methyl red test, Vogues Proskaur test, citrate utilization (IMVIC test) (Atlas \& Patks, 1993); catalase and oxidase activities (McCarthy \& Cross, 1983); triple sugar iron agar test (TSI); growth on MacConley 
medium; spore heat resistance (Harvey et al., 2001); Gram stain reaction. In addition, actinomycete isolate was evaluated for its ability to grow on SCA medium at different temperatures $\left(30-60^{\circ} \mathrm{C}\right)$ , $\mathrm{pH}(5.0-11.0)$ and $\mathrm{NaCl}$ concentrations (0.0$15 \%)$. Incubation temperature in all tests was at $55^{\circ} \mathrm{C}$; distilled water was substituted by artificial sea water. In melanin test, detection of deep brown to black diffusible pigment on at least one of the ISP test media indicated positive result $(+)$ and color absence was recorded as negative(-) (Ibrahim \& Abd El-Salam, 2016). In TSI test, results were evaluated in the form of slants alone and butt alone; the yellow colour is indicated as acidic reaction; while, pink colour is indicated as alkaline reaction. Results were recorded as follow: $\mathrm{A} / \mathrm{A}=$ Acid (slant), Acid (butt); A/Alk = Acid (slant), Alkaline (butt); Alk/A = alkaline (slant), Acid (butt); Alk/Alk = Alkaline (slant), Alkaline (butt). Gas detection liberated during reaction, hydrogen and carbon dioxide, were indicated by the presence of cracks in the media, bubbles or media removing from its original place.

Genomic DNA extraction and $16 S$ rRNA sequencing

Genomic DNA extraction, PCR mediated amplification of $16 \mathrm{~S}$ ribosomal DNA, purification of PCR products and sequencing of the PCR products for under study isolate were followed according to Ganesan (2017) with some modifications.

\section{Genomic DNA isolation}

The genomic DNA of undertreat strain S5 was isolated briefly as followed: purified cells of three days old cultured on starch casein broth (SCB) were collected by centrifuging at 12,000 r/min and re-suspended in $300 \mu 1$ Tris-Cl EDTA NaCl (TEN) buffers. $20 \mu \mathrm{l}$ of RNase was added, mixed and incubated for $2 \mathrm{~min}$ at room temperature, followed by addition of $20 \mu \mathrm{l}$ of proteinase $\mathrm{K}$ solution (20 $\mathrm{mg} / \mathrm{ml}$ ) and mixed well. Formed mixture was re-suspended and cells were transferred to the Hibead Tube, then incubated for $30 \mathrm{~min}$ at $55^{\circ} \mathrm{C}$. The mixture was subjected to vortexing for 5-7 min, incubation for $10 \mathrm{~min}$ at $95^{\circ} \mathrm{C}$, and pulse vortexing. Supernatant was centrifuged for 1.0 $\min$ (at $10,000 \mathrm{r} / \mathrm{min}$ ) at room temperature. This was followed by addition of about $200 \mu$ of lysis solution, mixing by vortexing then incubation at $55^{\circ} \mathrm{C}$ for $10 \mathrm{~min} .200 \mu \mathrm{l}$ of ethanol (96-100\%) was added to the lysate and mixed for $15 \mathrm{sec}$ by vortexing. The lysate was centrifuged at 10,000 r/ min for $1.0 \mathrm{~min}$. The lysate was then washed in
$500 \mu \mathrm{l}$ of prewash solution using centrifugation at $10,000 \mathrm{r} / \mathrm{min}$ for $1.0 \mathrm{~min}$. The lysate washing was repeated and centrifuged at $1000 \mathrm{r} / \mathrm{min}$ for 3 min. $200 \mu \mathrm{l}$ of the elution buffer was added and incubated for one min at room temperature. DNA Elution process was finished by centrifugation at $10,000 \mathrm{r} / \mathrm{min}$ for $1.0 \mathrm{~min}$. The DNA was dried and dissolved in $100 \mu \mathrm{l}$ TE buffer and stored at $-20^{\circ} \mathrm{C}$.

\section{Analysis and sequencing of $16 \mathrm{~S} r R N A$}

The 16S rRNA gene ribosomal sequence was amplified by polymerase chain reaction (PCR) using specific primers: $243 \mathrm{~F}$ with sequence 5-GGATGAGCCCGCGGCCTA-3 and A3R with the sequence 5-CCAGCCCCACCTTCGAC-3. It was amplified from genomic DNA in thermal cycler (ep gradient Eppendorf) whose conditions applied were: initial denaturation at $94^{\circ} \mathrm{C}$ for 3 min, 35 cycles of denaturation $94^{\circ} \mathrm{C}$ for $1 \mathrm{~min}$, annealing $54^{\circ} \mathrm{C}$ for $1 \mathrm{~min}$, extension $72^{\circ} \mathrm{C}$ for 2 min, and final extension $72^{\circ} \mathrm{C}$ for $7 \mathrm{~min}$ and finally hold at $4^{\circ} \mathrm{C}$. The PCR fractions were confirmed by $1.0 \%$ agarose gel electrophoresis.

\section{DNA sequence determination}

Automated sequencing was carried out according to the dideoxy chain-termination method using an ABI PRISM 3700 DNA sequencer.

\section{Phylogenetic studies and species identification}

Comparing of sequences similarity was confirmed with the species reference of bacteria contained in genomic database, using the "NCBI BLAST" tool (http://www.ncbi.nlm.nih.gov/ BLAST). The DNA sequences were aligned and phylogenetic tree was constructed based on bootstrap test of phylogeny with neighbourjoining method using MEGA4 software (www. megasoftware.net). The 16S rRNA sequence was submitted to the GenBank, NCBI, USA. Bootstrap values were determined according to Felsenstein's method (Felsenstein, 1985).

\section{Results}

\section{Actinomycetes isolation}

Isolation results of Alexandria, Egypt salinases samples (Burj Al-Arab, El-Agamy and Alex-Egypt rout) indicated that no thermophilic actinomycetes were present in all marine water samples under all applied conditions of isolation; while, a variety of thermophilic actinomycete strains were isolated from the sediment samples. High counts and diversities of actinomycetes were conducted on SNA with Burj Al-Arab sediment samples 
followed by Alex-Egypt rout as represented in Table 1. Burj Al-Arab samples (B \& C) at 7.0\% $\mathrm{NaCl}$ exhibited the highest actinomycete mean viable count (16.4 and $14.9 \mathrm{CFU} / \mathrm{g})$ of $\mathrm{SD}=$ 0.64 and 0.56 , respectively. However, recorded data of sediment samples (D, R, T, G, H, I) showed no or very weak actinomycete counts. Calculated count averages of actinomycete colonies and SD values for sediment samples were demonstrated in Table 1.

TABLE 1. Mean viable count (CFU/g) of thermophilic actinomycetes isolated from Burg El-Arab, El-Agamy and Alex-Egypt salinase sediment samples on starch nitrate agar at different $\mathrm{NaCl}$ concentrations.

\begin{tabular}{|c|c|c|c|c|c|c|}
\hline \multirow{2}{*}{$\begin{array}{l}\mathrm{NaCl} \\
\text { concentration } \\
(\%)\end{array}$} & \multicolumn{6}{|c|}{ Sediment sample / Mean viable count of actinomycetes $\times 10^{2}(\mathrm{CFU} / \mathrm{g})$} \\
\hline & $\begin{array}{c}\text { Burg El- } \\
\text { Arab }\end{array}$ & $\mathrm{CFU} / \mathrm{g}$ & $\begin{array}{c}\text { El- } \\
\text { Agamy }\end{array}$ & $\mathrm{CFU} / \mathrm{g}$ & $\begin{array}{l}\text { Alex- } \\
\text { Egypt }\end{array}$ & $\mathrm{CFU} / \mathrm{g}$ \\
\hline \multirow{4}{*}{2.40} & A & $5.10 \pm 0.15$ & $\mathrm{~F}$ & $6.40 \pm 0.40$ & $\mathrm{R}$ & - \\
\hline & B & $2.50 \pm 0.10$ & G & $0.10 \pm 0.02$ & $\mathrm{~S}$ & $5.50 \pm 0.10$ \\
\hline & $\mathrm{C}$ & $13.6 \pm 0.42$ & $\mathrm{H}$ & $0.10 \pm 0.01$ & $\mathrm{~T}$ & - \\
\hline & $\mathrm{D}$ & $0.10 \pm 0.01$ & I & $0.80 \pm 0.10$ & & \\
\hline \multirow{4}{*}{5.0} & A & $1.50 \pm 0.20$ & $\mathrm{~F}$ & $1.90 \pm 0.50$ & $\mathrm{R}$ & - \\
\hline & B & $11.9 \pm 0.60$ & G & $0.40 \pm 0.06$ & S & $4.0 \pm 0.38$ \\
\hline & $\mathrm{C}$ & $11.8 \pm 0.60$ & $\mathrm{H}$ & $0.10 \pm 0.53$ & $\mathrm{~T}$ & - \\
\hline & D & - & I & $0.40 \pm 0.05$ & & \\
\hline \multirow{4}{*}{7.0} & A & $0.30 \pm 0.11$ & F & - & $\mathrm{R}$ & - \\
\hline & B & $16.4 \pm 0.64$ & G & $0.30 \pm 0.04$ & $\mathrm{~S}$ & $3.10 \pm 0.45$ \\
\hline & $\mathrm{C}$ & $14.9 \pm 0.56$ & $\mathrm{H}$ & - & $\mathrm{T}$ & - \\
\hline & D & $0.20 \pm 0.08$ & I & - & & \\
\hline \multirow{4}{*}{9.0} & A & $0.20 \pm 0.04$ & $\mathrm{~F}$ & $0.50 \pm 0.30$ & $\mathrm{R}$ & - \\
\hline & B & $10.2 \pm 1.09$ & G & $0.20 \pm 0.08$ & S & $7.10 \pm 0.15$ \\
\hline & $\mathrm{C}$ & $5.2 \pm 0.64$ & $\mathrm{H}$ & - & $\mathrm{T}$ & - \\
\hline & D & $0.10 \pm 0.04$ & I & - & & \\
\hline
\end{tabular}

Actinomycete Antibiosis Screening test

Twenty isolates out of a total 135 thermophilic marine actinomycete recorded variable antibiosis efficacies. The maximum percentage of bioactive isolates was found in Burj Al-Arab (13 out of 20 isolates = $65 \%$ ) followed by 7 isolates from both El-Agamy and Alex-Egypt rout (35\%). Table, 2 recorded screening results of the 20 antagonistic bioactive isolates on testing media; it was noticed that the most susceptible test pathogen was Trichoderma spp.; while, Escherichia coli, Pseudomonas aeruginosa and Fusarium spp. were the most resistant pathogens. At 5.0\% $\mathrm{NaCl}$ in $\mathrm{SCB}$, most potent bioactive isolate of broad-spectrum antagonism and high stable antibiosis character was S5; its inhibition zone mean diameters were ranging between 18.0 and
$35.0 \mathrm{~mm}$ and SD values were achieved at 0.26 0.98 , respectively (Table, 2). S5 was followed by $\mathrm{F}$ strain under the same conditions with $\mathrm{SD}$ values of (0.50-0.71) and mean diameters of (15.6-20.0). S5 was selected for identification assay. As well, it was observed that type of culture medium and $\mathrm{NaCl}$ concentration affected isolate antagonism character.

\section{Identification of actinomycete strain S5}

Cultural and morphological characteristics Cultural properties study of isolate S5 grown on ISP media were presented in Table 3. Mature S5 colonies were noticed after 3 days of incubation; S5 showed abundant growth on three media; aerial and substrate mycelia colour were varied depending on the medium type; Diffusible pigments were not observed. 
TABLE 2. Antibiosis screening of salinases thermophilic actinomycetes cultured on three broth cultures at different $\mathrm{NaCl}$ concentrations in terms of mean diameter of inhibition zone $(\mathrm{mm})$.

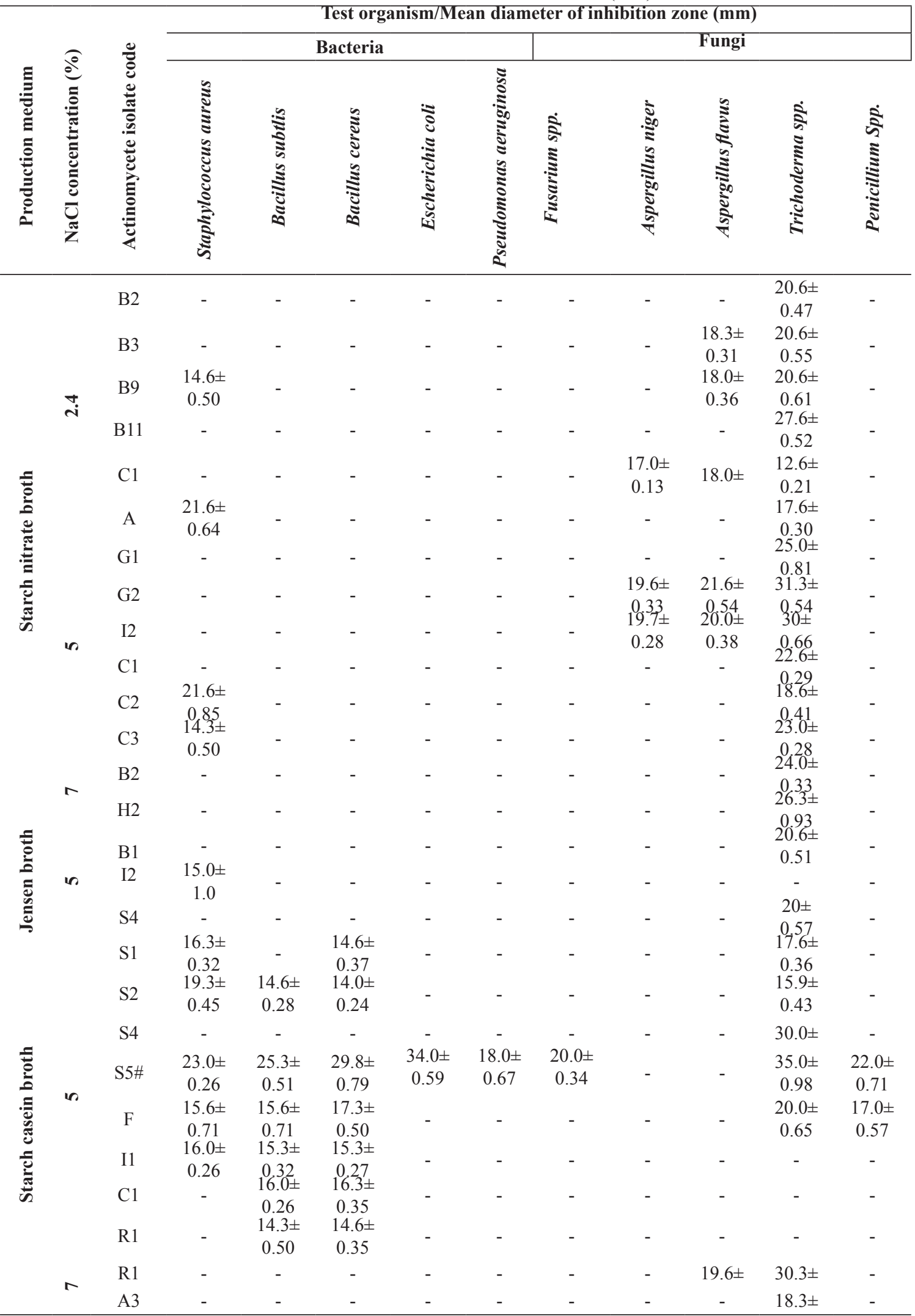

\# Most potent antagonistic isolate 
TABLE 3.Cultural characteristics of $\mathrm{S} 5$ mature colony grown at $55^{\circ} \mathrm{C}$ for 3 days on ISP media.

\begin{tabular}{|c|c|c|c|c|}
\hline Medium & Growth & Aerial mycelium & Substrate mycelium & Diffusible pigment \\
\hline $\begin{array}{l}\text { Glycerol asparagine agar } \\
\text { ISP2 }\end{array}$ & Abundant & $\begin{array}{l}\text { Powdery-Velvet } \\
\text { blue-grey }\end{array}$ & Very dark grey & Negative \\
\hline $\begin{array}{l}\text { Inorganic salt starch agar } \\
\text { ISP4 }\end{array}$ & Abundant & $\begin{array}{l}\text { Powdery-Velvet } \\
\text { greenish blue }\end{array}$ & Very dark green & Negative \\
\hline Oat meal agar ISP3 & Good & $\begin{array}{l}\text { Powdery grey- } \\
\text { greenish blue }\end{array}$ & Very dark green & Negative \\
\hline $\begin{array}{l}\text { Yeast extract-Malt extract } \\
\text { agar } \\
\text { ISP2 }\end{array}$ & Abundant & $\begin{array}{l}\text { Powdery-Velvet } \\
\text { bluish green }\end{array}$ & Black green & Negative \\
\hline
\end{tabular}

Morphological characteristics of mature colonies were examined using transmission and scanning electron microscopy. Scanning electron micrograph of S5 grown on SCA illustrated that spores are formed at the tips of simple unbranched sporophores of variable length (Fig.1). Spores are densely packed along the hyphae and appear as clusters (Fig.2). Single spores are observed only on the aerial mycelium either directly on the hyphae or on short sporophores. On SCA, oval warty surface spores were detected on transmission electron micrograph of S5 as demonstrated in Fig. 3.

\section{Chemotaxonomic characteristics}

Detection results of whole-cell hydrolysate analysis of S5 cells for diaminopimelic acid (DAP) revealed presence of chemo type IV cell wall characterized by Meso-diaminopimelic acid isomer in peptidoglycan and absence of glycine in S5 cell wall. Arabinose and galactose (sugar type A) were found in isolate cells.

\section{Physiological and biochemical characteristics}

Biochemical and physiological parameters' results of S5 were tabulated in Tables 4, 5, respectively. Strain S5 has the ability to utilize all tested carbon sources except xylose; it produces melanin pigment when cultivated on ISP1, ISP6 or ISP7; it can tolerate up to $7.0 \% \mathrm{NaCl}$ where only substrate mycelium grow, so it is a halotolerant isolate adapted to the marine environment but not a true marine microorganism. Good growth was recorded at a temperature range of $\left(35-57^{\circ} \mathrm{C}\right)$ with optimum at $55^{\circ} \mathrm{C}$; this indicated that $\mathrm{S} 5$ is a thermotolerant strain. S5 spores are heat sensitive. Isolate growth were detected at $\mathrm{pH}$ range of $(6-10)$. S5 is able to neither reduce nitrate nor produce $\mathrm{H}_{2} \mathrm{~S}$. For Gram stain reaction, isolate $\mathrm{S} 5$ is Gram +ve. In addition, S5 showed enzyme activities $\alpha$-amylase, gelatinase, tyrosinase, oxidase, catalase and urease; but cellulase was not detected.

The morphological, chemotaxonomic, physiological and cultural characteristics of S5 were compared with known actinomycete genera described in Bergy's manual of systematic bacteriology. It was suggested that S5 belongs to genus Saccharomonospora.

\section{Analysis of 16S rRNA gene sequence}

Analysis of 16S rRNA gene sequence was carried out under the automated sequencer (ABI PRISM 3700 DNA sequencer) (Fig. 4).The 16S rRNA gene partial sequence of S5 was compared with the nucleotide sequences of other Saccharomonospora species retrieved from NCBI Gene Bank database using neighbour- joining method. The strain has got maximum 16S rRNA sequence homology $(100 \%)$ with Saccharomonospora viridis. This 16S rRNA gene sequence analysis was carried out to elucidate the taxonomic position and relationships among closely related genus Saccharomonospora. The alignment result (Phylogenetic tree) was graphically summarized in Fig. 5. Therefore, isolate S5 was designated as Saccharomonospora viridis AHK190. 


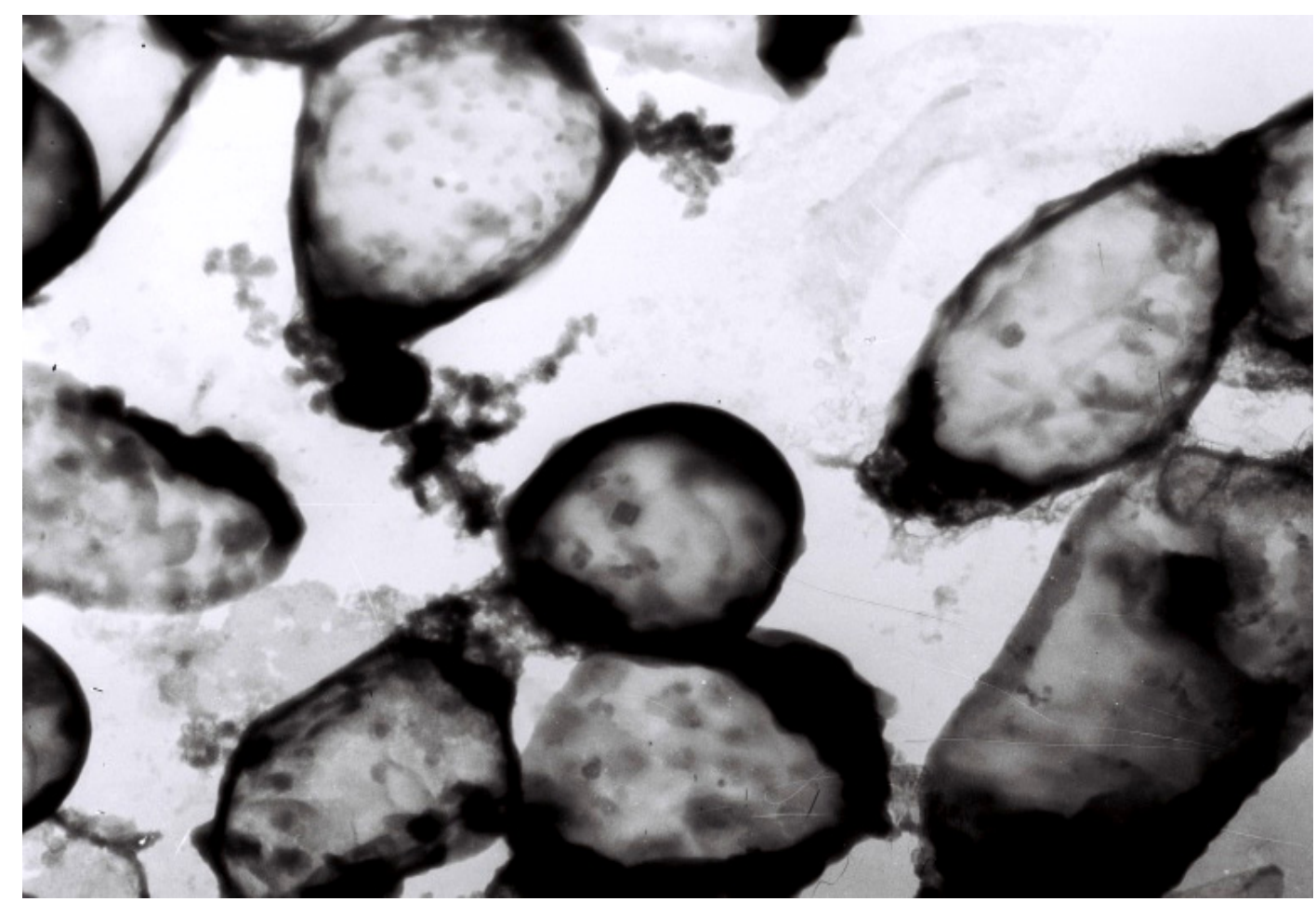

Fig .1. Sanning electron micrograph of S5 $(7000 \mathrm{X})$ cultured on SCA at $55^{\circ} \mathrm{C}$ for three days.

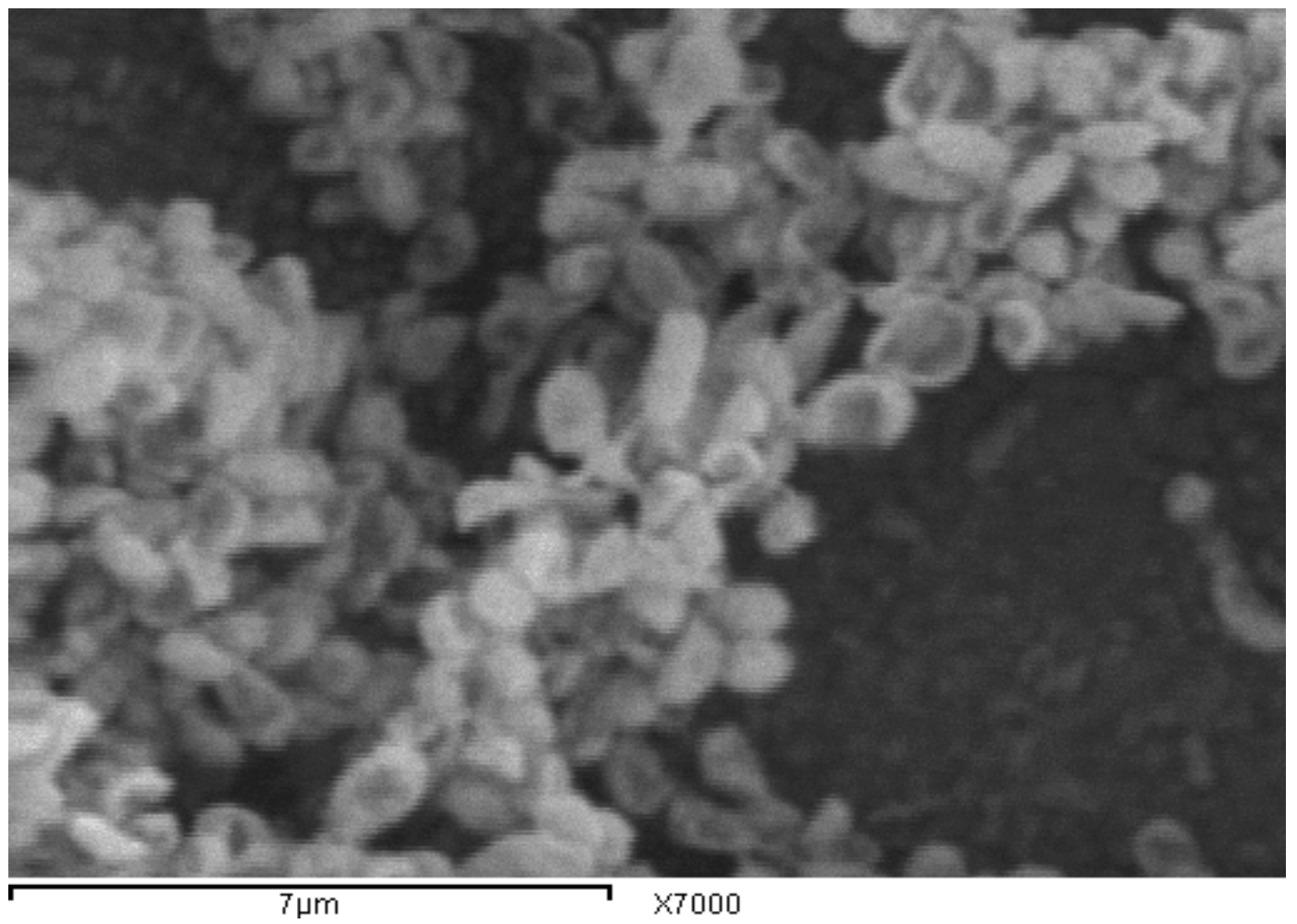

Fig.2.Scanning electron micrograph of S5 $(3000 \mathrm{X})$ cultured on SCA medium for three days. 


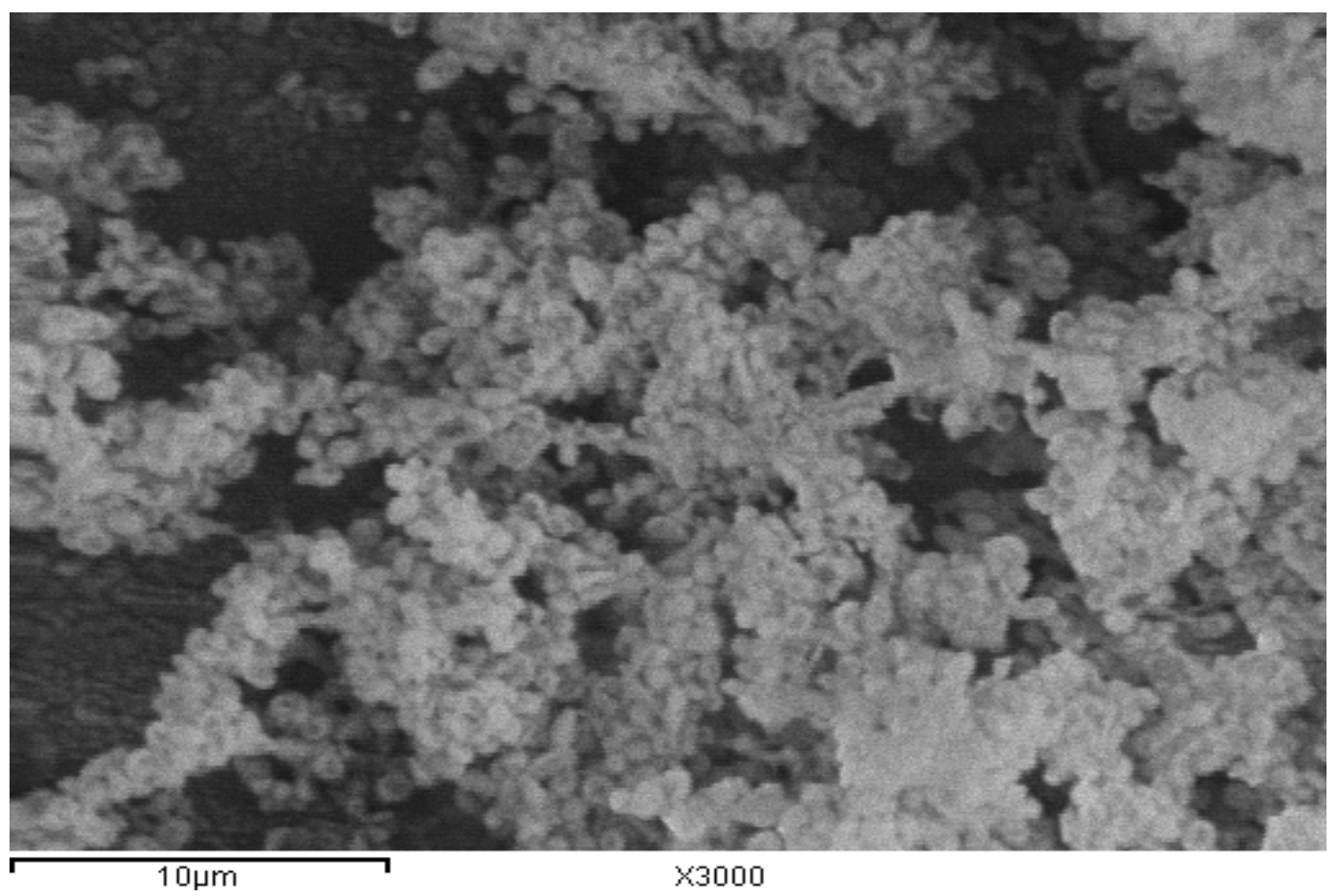

Fig.3. Transmission electron micrograph of S5 $(20,000 \mathrm{X})$ cultured on $\mathrm{SCA}$ at $55^{\circ} \mathrm{C}$ for three days.

TABLE 4. Biochemical characters of $\mathrm{S} 5$ cultured at $55^{\circ} \mathrm{C}$ for 3 days .

\begin{tabular}{lc}
\hline Character & Response \\
\hline Gram reaction & + \\
Catalase production & + \\
Oxidase production & + \\
Urease production & - \\
Hydrogen sulfide production & - \\
Nitrate reduction & + \\
Methyl red test & - \\
Vogues Proskauer test & - \\
Indole production & - \\
Citrate utilization & + \\
Starch hydrolysis & + \\
Gelatin liquefaction & Alk/Alk \\
Triple sugar iron & + \\
Casein hydrolysis & + \\
Heamolysis & Galactose \&Arabinose \\
Melanin production & + \\
Tyrosine decomposition & + \\
Cellulose decomposition & + \\
Cell-wall amino acids & + \\
Cell-wall sugars & Meso-DAP acid \\
\hline
\end{tabular}


TABLE 5. Physiological characterization of $\mathrm{S} 5$ cultured at $55^{\circ} \mathrm{C}$ for 3 days.

\begin{tabular}{|c|c|c|}
\hline Test & $\begin{array}{c}\text { Parameter } \\
\text { NaCl concentration }(\%)\end{array}$ & Response \\
\hline \multirow{9}{*}{ 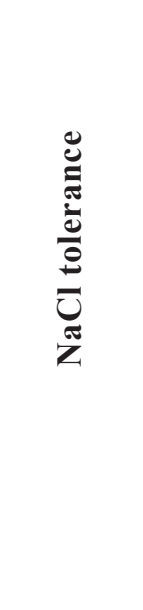 } & 0.0 & - \\
\hline & 1.0 & + \\
\hline & 3.0 & + \\
\hline & 5.0 & + \\
\hline & 7.0 & only substrate mycelium \\
\hline & 10.0 & - \\
\hline & 12.0 & - \\
\hline & 15.0 & \\
\hline & Carbon source & 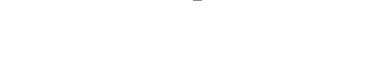 \\
\hline \multirow{11}{*}{ 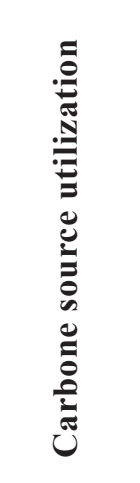 } & Glucose & + \\
\hline & Sucrose & + \\
\hline & Xylose & - \\
\hline & Meso-inositol & + \\
\hline & Galactose & + \\
\hline & Fructose & + \\
\hline & Lactose & + \\
\hline & Maltose & + \\
\hline & Rhamnose & + \\
\hline & Mannose & + \\
\hline & Arabinose & + \\
\hline \multirow{11}{*}{ 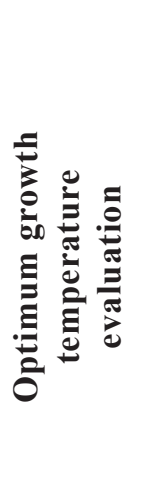 } & Temperature $\left({ }^{\circ} \mathrm{C}\right)$ & Growth density \\
\hline & 30 & \\
\hline & 35 & + \\
\hline & 40 & +++ \\
\hline & 45 & +++ \\
\hline & 50 & +++ \\
\hline & 55 & ++++ \\
\hline & 57 & +++ \\
\hline & 60 & ++ \\
\hline & & - \\
\hline & $\mathrm{pH}$ & \\
\hline \multirow{6}{*}{ 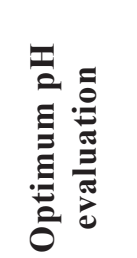 } & 5.0 & - \\
\hline & 6.0 & ++ \\
\hline & 7.0 & +++ \\
\hline & 8.0 & ++++ \\
\hline & 9.0 & +++ \\
\hline & 10.0 & +++ \\
\hline
\end{tabular}

$(+)$ response; (-) no response.

Dense growth $(++++)$; good growth $(+++)$; weak growth $(++)$; very weak growth $(+)$; no growth $(-)$ 


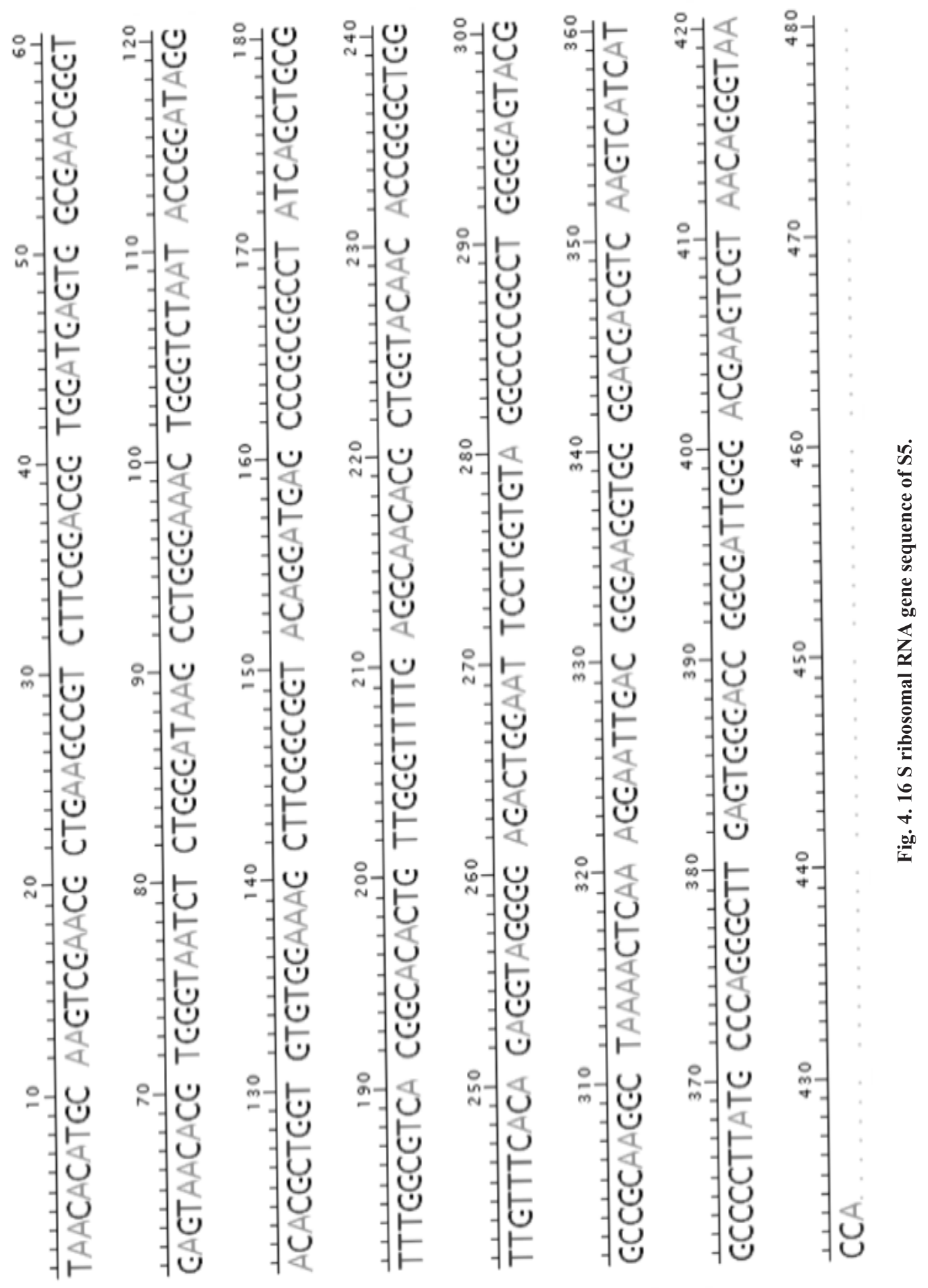




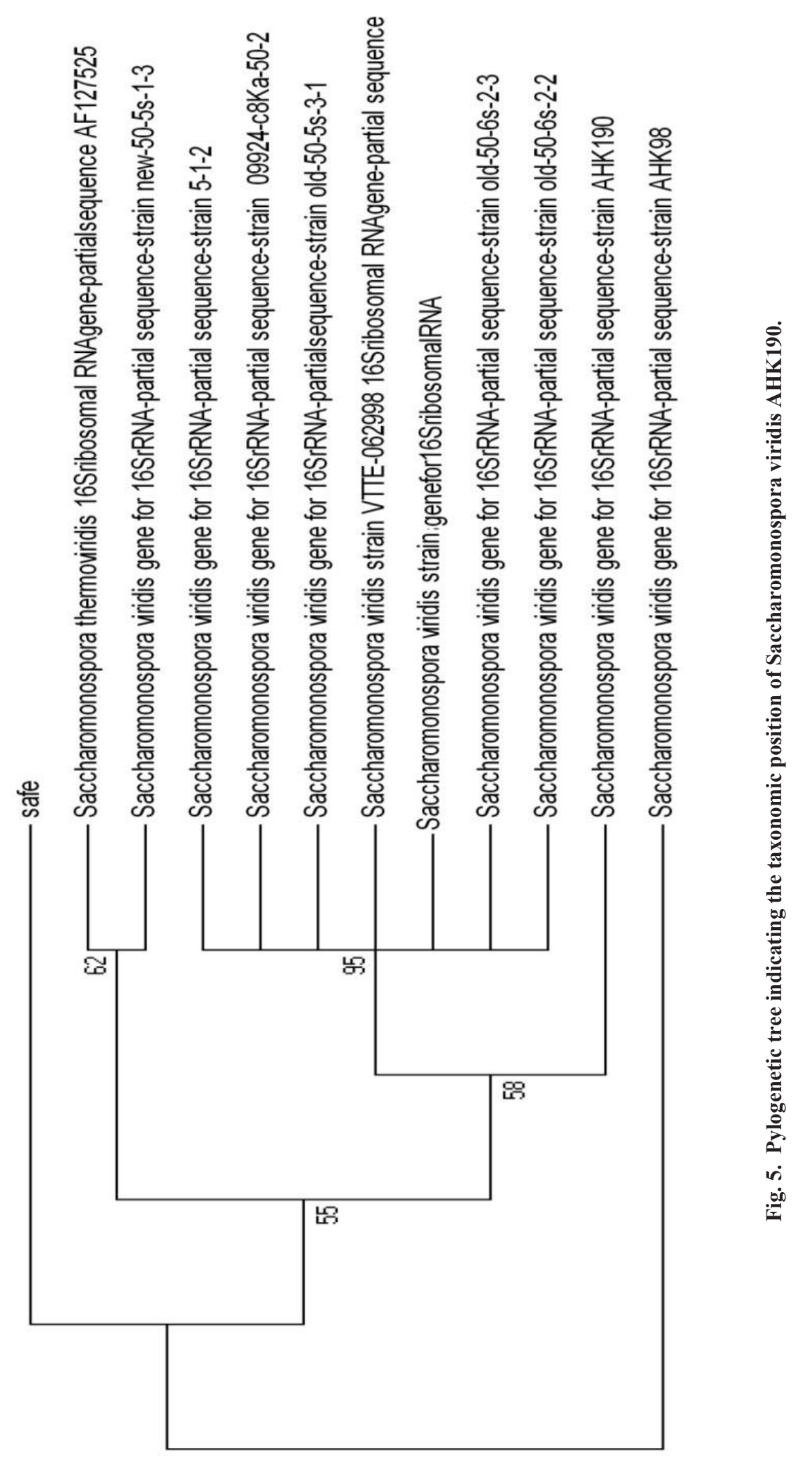

Egypt. J. Microbiol. 52 (2017) 


\section{Discussion}

The emergence of drug resistance to chemical drugs is the biggest threat in controlling human pathogens; current research objectives was designated in accordance with several studies based on this aim (Messaoudi et al., 2015; Ibrahim \& Abd El-Salam, 2016 and Ganesan et al., 2017). In present work, 135 isolates of actinomycetes were isolated from marine sediment soil habitat; and screened for their antibiosis activity against variable human pathogenic bacterial and fungal strains; 20 isolates registered detectable bioactivity. Messaoudi et al. (2015) mentioned that microbes from soils are the most important natural sources exhibiting strong biological activity against a wide range of pathogens; similarly, current investigation involved isolation from soil sediment. Abdelfattah et al. (2016) considered that seas and oceans are a valuable source for microorganisms and bioactive secondary metabolites; in accordance, study isolation habitat was a sea. Orlova, et al. (2015) examined marine actinomycetes as producers of secondary bioactive metabolites; as well, marine actinomycetes were the under test study target. Furthermore, in goal selection of Mediterranean Sea in present work as an isolation habitat was enhanced by the survey carried out by Tuncer \& Bizsel et al. (2017) who reported that there is a limited number of studies in sediments of Eastern Mediterranean Sea, especially in relation with environmental parameters, in spite of high morphological and phylogenetic diversity, biotechnological and economic importance of actinomycetes. A wide diversity of marine mesophilic actinomycetes were inspected for their bioactive compounds production (Eccleston et al., 2012; Orlova et al., 2015 and Subramanian et al., 2017), while thermophilic actinomycetes were not examined so far; accordingly, current investigation included them throughout. Maldonado et al., (2009) notified that previous works on marine sediments have been restricted to the isolation of members of the genera Micromonospora, Rhodococcus and Streptomyces while their study revealed that marine habitats are not restricted to these genera; this was found in parallel with our study findings which detected a member of genus Saccharomonospora as antimicrobial active potent isolate.

Different strategies could be employed in recovering members' of new antibacterial taxa such as using sample pretreatments (Tuncer \& Bizsel, 2017). Heat treatment which was used as a pretreatment of marine sediments reduced the numbers of Gram negative bacteria that commonly occur in marine samples and often overrunning the isolation plates (Vijayakumar et al. 2007). Also addition of $\mathrm{CaCO}_{3}$ to the isolation media will reduce the vegetative bacterial cells and allow many actinomycete spores to survive (Abo-Shadi et al., 2010).

Starch casein agar in present work was found the best recovery medium for marine actinomycetes which was, as well, revealed by Reddy et al. (2011) who reported that it is more effective in the isolation of marine actinomycetes; Starch as carbon source and casein as nitrogen source are found good for the development of actinomycetes. Using of rifampicin in current survey was found useful in actinomycetes isolation; it allowed to isolate actinomycete strains containing Meso-DAP like our isolate Saccharomonospora viridis AHK190; similarly this was boosted by the findings of Pisano et al. (1989) who registered that, the addition of rifampicin eliminates undesirable colonies of marine bacteria with mucoid nature and has a tendency to isolate a higher proportion of Meso-DAP- containing strains. All of the isolation media were prepared with artificial sea water at different concentrations of $\mathrm{NaCl}$ to enhance the chances of recovering obligate salt requiring actino-bacteria and to inhibit the number of fast growers (Maldonado et al., 2009) .

According to Bergey's Manual of Systematic Bacteriology (Whitman et al., 2012), present work applied recent characters in the description of undertreat isolate cultures together with traditional characters previously applied in Streptomyces description. Four of the various sugars occurring in the cell hydrolysate of actinomycetes proved to be of taxonomic relevance: arabinose, galactose, madurose and xylose (Lechevalier \& Lechevalier, 1970); culture examination of under test isolate indicated the presence of arabinose and galactose (sugar type A) and type IV wall chemotype. Micromorphological characteristics particularly of spore chains and spore surface ornamentation have been considered as major criteria in distinguishing spore forming actinomycete genera from each others and configuration of spore chain has played a prominent role in species descriptions as illustrated in Bergey's Manual (Whitman et al., 2012) . Electron isolate micrographs demonstrated no spore chains but only one warty surface spore originate on short sporophores; Micro-morphological isolate description together with cell wall chemotype confirmed taxonomy of genus Saccharomonospora according to Bergey's 
Manual (Whitman et al., 2012); Furthermore, current observations registered that examined isolate is characterized by producing grayish blue aerial mycelium, this color is important character for Saccharomonospora species. This was also emphasized by isolate heat sensitive monospores formed on the aerial mycelium. Moreover, present findings of isolate tolerance to temperature as thermotolerant, $\mathrm{pH}, \mathrm{NaCl}$ as halotolerant, complex compounds degradation ability and biochemical characters, as well confirmed the taxonomy of Saccharomonospora based on Bergey's Manual (Whitman et al., 2012). Actinomycetes were identified to genus and species levels in almost resent studies depending on molecular examinations (Sengupta et al., 2015; Abdelfattah et al., 2016 and Ganesan et al., 2017). Current molecular revolution seems to give us a more objective tool in taxonomy, first of all based on the characterization of the rRNA genes. The gene rRNA is the tool mainly used for molecular identification of bacteria. It is chromosomic gene present in all bacteria species (universal gene) whose sequence is specific to each species and whose ends 5'And 3' (15 first and 15 last bases) are conserved in all bacteria species. Evaluated 16S rRNA sequencing criteria resulted in $100 \%$ similarity to Saccharomonospora viridis which enhanced our announced taxonomy Saccharomonospora viridis AHK190.

\section{Conclusion}

The present finding shows the importance for further investigations towards the goal of obtaining novel antimicrobial agents. It is concluded that; the sediment samples of Alexandria salinases is a good source material for isolation of bioactive potential actinomycetes; thermophilic actinomycete could be regarded as antibiosis active agents; combination between sample pretreatment and suitable media supplemented with specific antibiotics, diverse rare actinomycete genera can be now successfully isolated while previously they were incidentally recovered only by conventional dilution-plating techniques .

Acknowledgement: The author gratefully acknowledges members of Faculty of Agriculture; Ain Shams University; Cairo; Egypt, for their generous assistance in providing fungal strains included in this work.

\section{References}

Abdelfattah, M.S., Elmallah, M.I.Y., Hawas, U.W.,
Abou El-Kassema, L.T. and Gamal, M.A. (2016) Isolation and characterization of marine-derived actinomycetes with cytotoxic activity from the Red Sea coast. Asian Pac J. Trop Biomed. 6 (8), 651-657.

Abo-Shadi, M.A., Sidkey, N.M. and Al-Mutrafy, A.M. (2010) Antimicrobial agent producing microbes from some soils rhizosphere in Al-Madina AlMunawwarah, K.S.A. J. American Sci. 6(10), 15925.

Atlas, R.M. and Patks, L.C. (Ed.) (1993) "Hand Book of Microbiological Media" CRC Press: Inc. Florida, U.S.A.

Battershill, C., Jaspars, M. and Long, P. (2005) Marine biodiversity: New drugs from the ocean depths. Biologist. 52, 107-114.

Blunt, J.W., Copp, B.R., Munro, M.H.G., Northcote, P.T. and Prinsep, M.R. (2007) Marine natural products. Nat. Prod. Rep. 24, 31-86.

Demain, L.A. and Davies, E.J (Ed.) (1999) "Manual of industrial Microbiology and Biotechnology". ASM Press, Washington, D.C."

Eccleston, G.P., Brooks, P.R. and Kurtboke D.I. (2008) The occurrence of bioactive Micromonospora in aquatic habitats of sunshine coast in Australia. Mar. Drugs. 6, 243-261."

El-Nakeeb, M.A. and Lechevalier, H.A. (1962) Selective isolation of aerobic actinomycetes. Appl. Microbiol. 11, 75-77.

Felsenstein, J. (1985) Confidence limits on phylogenies: an approach using the bootstrap. Evolution. 39, 783 791.

Ganesan, P., Reegan, A.D., David, R.H.A., Gandhi M.R., Paulraj, M.G., Al-Dhabi, N.A. and Ignacimuthu, S. (2017) Antimicrobial activity of some actinomycetes from Western Ghats of Tamil Nadu, India. Alex. J. Med. 53, 101-110.

Gontang, E.A., William, F. and Jensen P.R. (2007) Phylogenic diversity of gram positive bacteria cultured from marine sediments. J. Appl. Envir. Microbial. 73(10), 3272-3282.

Gordon, R.E. and Mihm, J.M.A (1956) comparative study of some strains received as Nocardia. Instit. Microbiol. Rutgers Univ.

Gordon, R.E. and Smith , M.M. (1954) Proposed group of characters for the separation of Streptomyces and Nocardia. Instit. Microbiol. Rutgers Univ.

Harvey, I., Cormier, Y., Beaulieu, C., Akimov, V.N., 
Meriaux , A. and Duchaine, C. (2001) Random amplified ribosomal DNA restriction analysis for rapid identification of thermophilic actinomycete-like bacteria involved in hypersensitivity peneumonitis. J. System. Appl. Microbiol. 24, 277-284.

Ibrahim, S.Y. (2002) Microbiological and biochemical studies on bioactive actinomycete products. $P h D$ Thesis. Botany Department, Faculty of Women for Arts, Science and Education, Ain Shams Univ., Egypt.

Ibrahim, S.Y. and Abd El-Salam M.M. (2016) Isolation of anti-fungal agent from a soil inhabitant Streptomyces albaduncus-M51 and its efficacy against osmophilic food spoilage by Saccharomyces cerevisiae. J. Environ. Occup. Sci. 5(2), 38-46.

Kafilzadeh, F. and Dehdari, F. (2015) Amylase activity of aquatic actinomycetes isolated from the sediments of mangrove forests in south of Iran. Egyp. J. Aquatic Res. 41, 197-201

Kenneth, L.K. (1976) The Universal Color Language. In: "Color Universal Language and Dictionary of Names". U.S., Washington, D.C. Nat. Bur. Stand.

Kokare, C.R., Mahadik, K.R., Kadam S.S. and Chopade, B.A. (2004) Isolation, characterization and antimicrobial activity of marine halophilic Actinopolyspora species AH1 from the west coast of India. Curr. Sci. 86, 593-597.

Lechevalier, M.P. and Lechevalier, H. (1970) Chemical composition as a criterion in the classification of aerobic actinomycetes. Int. J. Syst. Bacteriol. 20, 435-443

Maldonado, L.A., Fragoso-Yanez, D., Perez-Garcia, A., Rosellon-Druker, J. and Quintana, E.T. (2009) Actinobacterial diversity from marine sediments collected in Mexico. Antonie Van Leeuwenhoek, 95, 111-120.

McCarthy, A.J. and Cross, T. (1983) A taxonomic study of Thermomonospora and other monosporic actinomycetes. J. Gen. Microbiol. 130, 5-25.

Messaoudi, O., Bendahou, M., Benamar, I. and Abdelwouhid, D. (2015) Identification and preliminary characterization of non-polyene antibiotics secreted by new strain of actinomycete isolated from sebkha of Kenadsa, Algeria. Asian Pac. J. Trop. Biomed. 5(6), 438-445.

Orlova, T.I, Bulgakova V.G. and Polin A.N. (2015) Secondary metabolites from marine microorganisms. I. Secondary metabolites from marine actinomycetes. Antibiot Khimioter, 60, 47-59. Russian.
Pisano, M.A., Sommer, M.J. and Brancaccio, L. (1989) Isolation of bioactive actinomycetes from marine sediments using rifampicin. Appl. Microbiol. Biotechnol. 31, 609-612.

Pridham, T.G. and Gottlieb, D. (1948) The utilization of carbon compound by some actinomycetes as an aid for species determination. J. Bacteriol. 56, 107 114. Rutgers Univ.

Reddy, N.G., Ramakrishna, D.P.N. and Gapol, S.V.R. (2011) A morphological, physiological and biochemical studies of marine Streptomyces rochei (MTCC10109) showing antagonistic activity against selective human pathogenic microorganisms. Asian J. Biol. Sci. 4(1), 1-14.

Sengupta, S., Pramanik, A., Ghosh, A. and Bhattacharyya, M. (2015) Antimicrobial activities of actinomycetes isolated from unexplored regions of Sundarbans mangrove ecosystem. $M C$. Microbiol. 15, 170.

Sharma, M., Dangi, P. and Choudhary, M. (2014) Actinomycetes: Source, Identification, and Their Applications. Int. J. Curr. Microbiol. App. Sci. 3(2), 801-832.

Shirling, E.B. and Gottlieb, D. (1966) Method for characterization of Streptomyces species. Inter. J. Syst. Bacteriol. 16(3), 313-340.

Staneck, J.L. and Roberts, G.D. (1974) Simplified approach to identification of aerobic actinomycetes by thin layer chromatography. Appl. Microbiol. 28, 226-231.

Standard, Deviation Calculator, Calculator.net, sitemap (C) 2008 - 2017 calculator.net, http://www. calculator.net/standard-deviation-calculator.html

Subramanian, D., Kim, M., Kim, D. and Heo M. (2017) Isolation, Characterization, Antioxidant, Antimicrobial and Cytotoxic Effect of Marine Actinomycete, Streptomyces carpaticus MK-01, against Fish Pathogens. Braz. Arch. Biol. Technol. 60, e170539

Trabelsi, I., Oves, D., Magan, B.G., Manteca, A., Genilloud, O. and Nour, M. (2016) Isolation, characterization and antimicrobial activities of actinomycetes isolated from a Tunisian Saline wetland. J Microb. Biochem. Technol. 8, 6

Tuncer, I. and Bizsel, N. (2017) Phylogeny and physiology of Actinomycetes and biogeochemical parameters in sediments of Eastern Mediterranean Sea. Inter. J. Environ. Sci. and Development, 8(8), 581- 585 . 
Valli, S., Suvathi, S.S., Aysha, O.S., Nirmala, P., Vinoth, K.P. and Reena, A. (2012) Antimicrobial potential of Actinomycetes species isolated from marine environment. Asian Pac. J. Trop. Biomed. 2(6), 469-473.

Vijayakumar, R., Muthukumar, C., Thajuddin, N., Panneerselvam, A. and Saravanamuthu, R. (2007) Studies on the diversity of actinomycetes in the Palk Strait region of Bay of Bengal, India. J. Actinomycetol. 21, 59-65.
Whitman, W.B., Goodfellow, M., Kämpfer, P., Busse, H.J., Trujillo, M.E., Ludwig, W. and Suzuki, K. (2012) "Bergey's Manual of Systematic Bacteriology", 2nd ed., Vol. 5, Parts A and B, Springer-Verlag, Ed., New York, NY.

Williams, S.T. and Cross, T. (1971) Isolation, purification, cultivation and preservation of actinomycetes. In: "Method in Microbiology" Norris, J.R., Ribbons, D.W. (Ed), pp.295-334. 4.London: Academic Press.

(Received 8/11/2017; accepted 23 / 11 / 2017)

\title{
عزل وتعريف للأكتينوميسيتات البحرية المحبة للحرارة المرتفعة وكفاعتها ضد الميكروبية
}

\author{
سحر يس إبراهيم \\ قسم النبات ـ كلية البنات للأداب و العلوم و التربية ـ جامعة عين شمس ـ القاهرة ـ مصر.
}

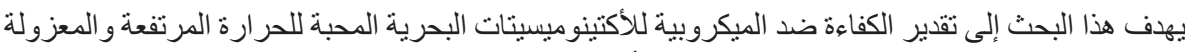

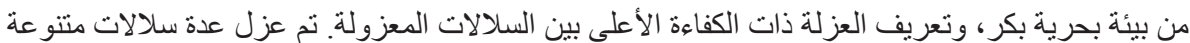

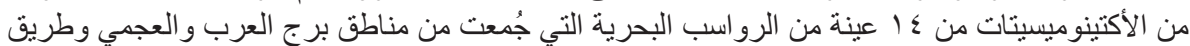

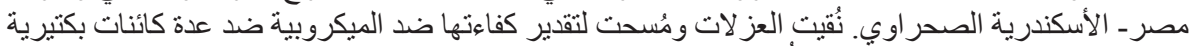

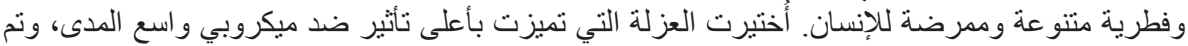

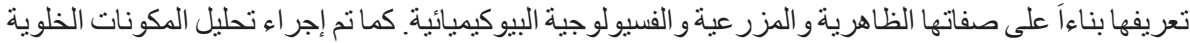

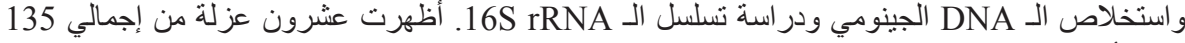

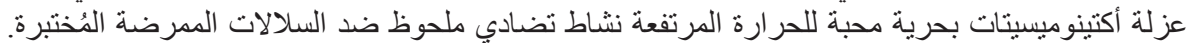

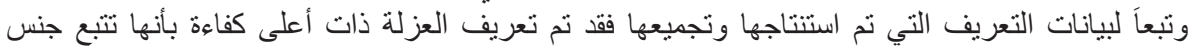
Saccharomonospora

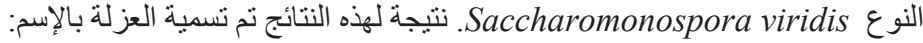
Saccharomonospora viridis AHK 190
\end{abstract}

